\title{
Inclusion, democracy
}

\section{and new developmentalism - a historical assessment}

\section{VERA ALVES CEPÊDA}

\section{Development and developmentalism}

7 HE TERM development is admittedly controversial and its meaning generates serious discrepancies in the political and intellectual debate.

L Part of this tension stems from its conceptual polysemy, as it covers numerous areas and different historical moments, nestling in the heart of some of the most complex theoretical schools produced in more than four centuries of Western thought. The first difficulty in addressing the topic of development is its proximity to two equally arduous concepts: the notions of evolution and progress. The second difficulty is to separate development from developmentalism.

Let us take a closer look at the first issue. Development, evolution and progress are topics dear to modern thought, either in philosophical reflection, historical debate, or original economic theses. Condorcet and Herder can be mentioned as thinkers who first addressed the issue of the difference of human and social relations at successive levels of temporal and qualitative change as an evolutionary scale of the development of man and society. Later on, philosophers such as Kant, Hegel, Marx and Comte addressed the same issue seeking to reveal the rationale that caused this evolution and its fate, strengthening the epistemological perspective of the philosophy of history or transformation focused on the movement of social forms. Regardless of all the theoretical diversity found in these authors, which oscillates between metaphysics and materialism, the core of the historical dimension as the locus of a change that rose to increasingly sophisticated moments of existence united them under the principle of evolution, of development, of a forward movement driven by human action. Qualitative change, in the axis of history, such as the achievement of an energy that renews itself, is the principle of the synthesis contained in the idea of progress, evolution and development. Regardless of the establishment of the engine or Subject of this change (Reason, History, social class or individual) or of the purpose of its achievement, the canon of development laid a solid foundation in the intellectual thought of the eighteenth century and subsequent centuries.

Charles Darwin's thesis is another important source of support for the 
meta-perception of development, by postulating the logic of evolution as an explanatory key to the diversity and plurality of organic life. Subsequently, the effects of this assumption based on the elements of competition and endurance and the modus operandi of biological evolution would be adapted to studies in the field of humanities. Evolutionism assimilated a value-oriented scale for the cultural, political and economic diversity found in different societies integrated by the Overseas Expansion and by mercantilism, in the form of social Darwinism. The difference among cultures was included in a global scheme focuses on the European pattern and, staggering them as steps or stages of development in terms of a unitary albeit uneven concept of history.

In classical economic thought, the topic of development was covered by Adam Smith in what was perhaps the longest lasting version of the idea of progress: that which, springing from the energy of human labor, socialized by the division of production (in the factory or in the factory-market-society relation), forged the doors to the future by increasing industrial production and, as a result, improving human well-being. In the reasoning of The Wealth of Nations we find the central elements of the ethos of modernity: the prominence of labor as a form of Man's autonomy over nature, the perception of the organized system of labor division, the prospect of productivity and innovation, the space of subjective freedom moving the engineering of productive action and, as a result of this conjunction of elements, the change and improvement of the social conditions of existence along a progressive continuous curve. Regardless of how much the economic theories may have subsequently challenged, cropped or reframed the classic liberal argument, this assertion of progress based on constant changes in the world of production has not been outdone, as neither has its bond as the basis of social - and therefore human - achievement.

Even if the place and form of labor in modern or hypermodern society is challenged, the replication of production mechanisms remains as a backdrop and conditioning factor of the social future. The differences occur in the process of explaining the economic dynamics, in the detection of the fundamental variables of this movement and in the definition of the intended purpose of development. In this context we find the most commonly mentioned diatribe between growth and development, guided strongly by the dispute between the paradigm of economics on the supply side versus economics on the demand side, between market autonomy (via an invisible hand) versus macroeconomic 'regulationism' - issues that separate the competing fields of neoclassical and Keynesian economics. But it is in this scenario that the meaning of development is separated from that of developmentalism.

At the risk of controversy, I think that in the general economic argument development is a relatively neutral concept, since it implies the act of developing, the exponential evolution of the energy contained in the forms of production. With the exception of schools that reject the pattern of a society focused 
on capitalist production and consumption (Sachs, 2000), the link between the increasing productive potential and the achievement of autonomy by nations and individuals is usually accepted as necessary. Even if we raise the issue that production is not synonymous with distribution, this discussion could not even be considered before the first is achieved as the basis for providing the latter. Neither individuals nor governments want scarcity but rather its elimination. The long lasting hegemony of progress based on an economic foundation rests on this assumption.

In the context of the economic theory, the distinction between growth and development mirrors the conflict between a naturalistic view of the production process (the free market assumption and the profit maximization logic) and a view that ascribes private rational calculation a potential for serious disturbances. In the first key any extra-economic action can inhibit the fundamental mechanism of free enterprise, whereas in the second the crisis (predictable and inherent in economic naturalism) requires corrective mechanisms with some degree of non-individual rationalization, adopting in its place a systemic and regulatory view of the economic ensemble. This engineering, at a largely institutional and political level would absorb in its complex the various stages, functions and dysfunctions of the economic structure, observing the pulse and timing of production, (external, internal, regional, sectoral, short and long term) of consumption, of the savings and investment capacity, of the impetus for innovation, of the soundness of the currency and its pattern in world trade, etc. The economy is seen here in a network, and can and should be corrected in its dysfunctions as a means of unshackling the critical points. Automatism versus regulation is a complex and very tense field because it implies the definition of the ratio of economic movement, becoming the central arena in the confrontation between the growth and development concepts. We can thus refer to development policies as those that promote the economy outside the primacy of laissez-faire.

Another gray area arises when dealing with the issue of developmentalism. The addition of the suffix $i s m$ to the word development indicates the aspect of process, of movement with social dimension, generating historical paradigms, chains and especially configurations. I would like to address more closely here the minimal definition of this concept by associating it with the theme of the capitalist periphery, the specific situation of its emergence and its processing. In general, developmentalism can be defined as a project of deep social transformation, politically operated in a rational manner and oriented by the State, linking economy and social progress. If this definition is correct, developmentalism emerges from the verification of a structural and chronic deficiency as the logical basis of intervention for the purpose of transformation. Therefore, it is more than development: it is a systemic, oriented and politically sustained change. Seen as a project, developmentalism is the product of a dated time and of a specific context, but even in this modality it was able to produce a theoret- 
ical and political arrangement capable of being updated and realigned in other historical situations.

In the proposed definition, the historical moment of its genesis, the specific theoretical argument and the policy implications of the project are crucial. Developmentalism emerged as a derivation of the backwardness thesis and many were the contributions to the configuration of its explanatory field. From List's original contribution in The National System of Political Economy (published in 1841), the theses of Manoilescu, Rostow, Nurske, Lewis, Agarwala, and Singh, to the formulations closest to the Brazilian case, such the ECLAC concepts and the theoretical developments of Roberto Simonsen and Celso Furtado, we have a common framework for understanding backwardness from the situation of late capitalism. The common element in these theses is the existence of obstruction in the maturation of production and modernization processes in laggard countries. The path of industrialization does not start or does not end largely as a result of the unequal positions of more and less advanced economies in the international trade circuit. Thus, the obstacles to progress towards full modernity would not arise from a pre-modern, feudal or non-capitalist situation, but by conditioning factors engendered by capitalist modernity itself. They are the result of historical relations that sprouted in the design effected by colonialism, by mercantile expansion, by the architecture of Ricardian international trade and by new forms of economic domination that included while excluding, in view of the subordinate and complementary situation (usually in the formula of the primary-export model). Backwardness emerges, then, as unfinished, incomplete capitalism: an expression of underdevelopment.

One of the consequences of the effects of the economy of underdevelopment was to question the neutrality and universality of capitalist dynamics in the global geo-economic constellation. Dysfunctions in global labor division, between industrial and primary-export economies imply the emergence of various national problems for the second group, especially in the long-term capacity for growth, productive diversification, innovative leaps and domestic market expansion. Economic issues are therefore associated with autonomy issues. The causes raised by the theory of underdevelopment will give rise to both developmentalism (proposal for overcoming underdevelopment) and national developmentalism (social pact that underpins the proposed intervention and means for the construction of the nation, which is classical in Brazil and Latin America).

Developmentalism is the other side of the underdevelopment thesis, attached to the same explanatory principle: the acceptance of economic causality implies a set of prescriptions also guided by economic solutions. And this combined movement strays from the paradigms of classical economic theory in two essential aspects: in the recognition that the pathology of underdevelopment results from the perverse effect of the invisible hand theory (which works backwards in primary-export economies) and in the pathology of structural 
bottlenecks, of technological backwardness and of the limits of endogenous investment, present even in situations of SOP (Rostow, 1964; Nurske, 1957) or historical gaps (Furtado 1995, 1967). Both the formation of underdevelopment (commodity-export model) and the situation of historical gap/SOP, central tenets of liberalism such as the premise of competitive advantages, progressive inertia of SOP, and decision-making autonomy of private economic agents are rejected. Overcoming underdevelopment will require, on the contrary, the heterodox resource of planning and rationalization, so that the vicious circle of underdevelopment can be broken through skipping steps and the transforming action of the State. The possibility of economic and social development depends on an artificial project that thinks and guides the production world. Far from the private vices, public benefits model in which social progress is the effect of economic action, planning for development - developmentalism - reverses the vector by placing social will as a the source of progress dynamics. The developmental project is based on path dependency, on the prospect of changing the past (backwardness) and on the construction of the future (progress, autonomy, sovereignty and nation).

National developmentalism is the result of this confluence that involved a particular historical situation (the situation of late and peripheral capitalism and, in many cases, colonial heritage), the production of an explanatory complex broken by economic liberalism (unable of solving the peripheral backwardness issue) and the social effort condensed into a national project based on overcoming underdevelopment through economic modernization. It should be noted that this is a generic perspective in which, given the conceptual abstraction, the phenomena may appear homogeneously. Each particular situation approaches this ideal typology while straying from it due to their factual specificities. The contribution of Falleto \& Cardoso (1969) shows that each dependent experience is national and has an architecture of its own, the result of its historicity, economic arrangements and established political pacts (outwards and inwards). However, despite specific experiences, the national developmental model expanded to numerous countries in its heyday, with its most important moment between the 1950s and 1970s, resulting in the major modernization project of the capitalist periphery.

\section{Conceiving developmentalism in Brazil}

Both the underdevelopment thesis and the developmental project played a key role in the construction process of Brazilian modernity. These two influences have permeated the national political and intellectual debate long before its clearer and better defined formulation in the 1950s. Developmentalism can be associated with two distinct conceptual keys, recombined in their formulation. The first, endogenous to Brazilian social and political thinking, is linked to the intellectual perception of national identity deficit resulting from the colonial legacy, the ethnic mix, regional differences or the limits inherent in the 
emergence of modern rationality (regional ethos of labor and individualism). The second key is the one linked to a theoretical field from which it rejects the spontaneity of social relations as parti pris for the generation of social progress, economic balance or emancipation, straying from the liberal field and approaching corporate or organic conceptions.

The intellectual movement that conceives the construction of the nation based on overcoming its deficiencies dates back to the late nineteenth century, in authors such as Nabucco, Euclides da Cunha, Alberto Torres, Gilberto Amado, Oliveira Vianna, Manoel Bonfim, Gilberto Freyre, Sérgio Buarque de Holanda, among many others. But the association between this gap and the determination of the economic order belongs to authors who stressed the weight of the primary-export legacy in the bias of economic formation, such as Roberto Simonsen, Caio Prado Jr., and Celso Furtado. The term undercapitalism (meaning a peripheral, specialized and dependent situation, responsible for hampering national development) first appeared as a theoretical 'corpus' in Roberto Simonsen in the 1930s, when he said that Brazil was a poor country due to the difficulty of "achieving a high quotient if the divisor is weak and the dividend grows continuously". ${ }^{1}$ In the late 1940s the idea of underdevelopment began to gain a hegemonic dimension, albeit understood and theorized in different ways. It became a kind of historical bloc capable of organizing different sectors and social groups in an related field, in the task of overcoming backwardness through the economic path.

The intersection between the economic argument and the political dimension emerges with the social issue, which was fundamental in the Brazilian transformation process of the 1920s and 1930s. The crisis started in 1930 expressed the process of structural transformation of society, but was unable, however, to produce a related political hegemony (Cepêda, 2010). The 1950s became the golden moment in this transformation process by consolidating a social pact with high hegemonic capacity - national developmentalism - characterized by the presence of a thoroughly modern agenda and actors. Waged workers and entrepreneurs of various classes (linked to the interests of industry, trade, agriculture; split between internal and external dynamics), urban middle classes, civil servants and intellectuals with the power or state-makers intertwine in the debate on the configuration of a modern society (of an urban-industrial model), defined as a national project. $^{2}$ The national developmental project carved in the 1950 s would only end with the 1988 Constitution and the State Reform, which disrupted the structure of the Brazilian Leviathan (Sallum Jr., 2003). This long period called old developmentalism includes, however, two very different political moments: the democratic phase and the military regime. Having as a gap the period of economic stabilization and the Reform of the State in the 1990s, the return to various aspects of developmentalism is detected in the last decade, but with a different guise and new commitments, which earn it the name of new developmentalism. 
We thus have a long wave (developmentalism), two major phases (old and new developmentalism) and three short waves, oscillating in the democratic or non-democratic spectrum (national developmentalism with democracy, authoritarian national developmentalism and the current new developmentalism). In this scenario it is possible to recognize that developmentalism has become a large project, with contradictory sides and allowing the construction of more than a single pact in the massive developmental bloc. Taking the Salte Plan and the Manifesto of the Peripherals as the inaugural landmark of the developmental model, both in the late 1940s, we can see that developmentalism spread over two major phases and at least three waves, marked by the problem of production versus distribution and the democratic issue.

The long wave of Brazilian developmentalism can be legitimized as one of the moments of the organic lineage of Brazilian political and social thought, as part of that intellectual tradition grounded in the leading role of the State, required to overcoming the structural problems of a hypo-sufficient society (Brandão, 2007). The adoption of this organic lineage perspective is important, as it indicates the permanence, in the national intellectual and political culture, of the trend to reduce the power of civil society and strengthen the capacity of the State. Developmentalism would thus be included in a backdrop that precedes it historically (the fine and synthetic enunciation of "organic idealism" appears in 1927 in O idealismo da Constituição, by Oliveira Vianna [1927]), which is perhaps the origin of its hegemony and persistent trajectory. However, recognition of developmentalism as part of a "political and intellectual family" focused on organicism and the central role of the State does not prevent its development into authoritarian or progressive commitments. The presence of the developmental organic lineage gained shape after 1930, with ideologically competing actors in the left-right field, leaning to the field of planning and state intervention driven by the explanatory power of the underdevelopment perspective (although supported by several logics in specific cases). ${ }^{3}$

Brazilian developmentalism has a common theoretical framework guided by the suspicion or rejection of the virtues of social self-organization (from the market, the leadership of individuals or political competition) as an incentive to progress and development in general. This statement gave rise to the propensity towards a more organic perspective. This long wave houses both the perception that the latch of development is the failure to produce (old developmentalism) or the inability to distribute (new developmentalism). Between the two extremes lies a delicate complex aspect which, in addition to the economic problem, also has to deal with the social and political aspects in the construction of development, by addressing competing demands, interests, ideologies and projects in shaping-up social commitments in each moment (Bresser-Pereira 2009, 2012).

\section{Between old and new developmentalism}

The formula of old developmentalism can be summarized in six key argu- 
ments: 1) understanding the economy as an integrated national system, a whole that cannot be reduced to productive sectors, regions or actors; 2) criticism of market automation and, consequently, abandonment of economic liberalism matrices; recognition of state regulation mechanisms and policies to stimulate/ unshackle production, linking economy and politics, with a deep social transformation role; 3 ) preponderance of industrial interests as a driving factor of the dynamic chain of the economy (in this case accepting the argument of economy alongside supply); 4) external versus internal opposition, relying on a theory of antagonism between global and national interests, strengthening protectionist barriers and heavy investments in the most vital sectors of the domestic economy; 5) overcoming the paradigm of liberal expertise (competitive advantages) and effort to develop a diverse, autonomous and complete economic apparatus, especially in strategic sectors (infrastructure, basic industry, technological industries and professional qualification); 6) directive role of the state through planning and the idea of nation as the basis of this social pact.

Old developmentalism, starting from and attached to the diagnosis of underdevelopment, elects as central the problem of barriers to the completion of a complex and mature industrial economic system. The focus on old developmentalism is based, essentially, on the bottlenecks of the production world and on their resolution via heavy industrialization. In the background, and if anything in the horizon of their proposition and as an effect of their action, are the aspects of distribution and improved well-being. The motto growing first and distributing later ${ }^{4}$ is no accident, but rather an illustrative metaphor of the social commitment and costs required by the development project. ${ }^{5}$

New developmentalism, in contrast, relies on the social inclusion process, placing redistribution and equity in a priority position. Distinguishing between the two phases is not an easy or smooth task, especially when economic dimensions and those of political (or causation) scope intersect in said distinction. The national question that consolidates new developmentalism, present in the federal public policies of the last decade and its Support Project (PAC I and PAC II ), relies on the diagnosis of social exclusion as the axis of the current problem (cf. Albuquerque, 2011; Pochmann, 2010).

Reaffirming the commitment of Article 3 of the Constitution of 1988 "I to build a free, just and solidarity society; II - to guarantee national development ; III - to eradicate poverty and substandard living conditions and to reduce social and regional inequalities; IV - to promote the well-being of all, without prejudice as to origin, race, sex, color, age and any other forms of discrimination," the topic of inclusion and equity gained prominence in the federal government's documents and letters of intent in its recent actions, including the current government slogan: "Brazil - a rich country is a country without poverty."

New developmentalism combines growth policies with distribution policies (Sicsú et al, 2009; Sicsú \& Castelar, 2009), but it might be interesting 
to notice that the position of the second objective has changed position in the developmental constellation, becoming the epicenter of the project and accompanied by productive incentive policies, in the format of a plus of developmental sectoral strategies. The formulation of policies of incentive to productive/economic development is the mandatory basis of any developmental project, and the source of distributive resources and strengthening of all productive social forces $^{6}$ - here understood as the sum of knowledge, capacity and autonomy, scattered over both the classical factors of the economy such as capital (entrepreneurs, resources, technological level) and those contained in the world of labor, in culture, in citizenship and in institutions (Sen, 2000; Pochman, 2010). In this context, developmental strategies are segmented into key sectors such as innovation economy, sustainability economy, export economy, accompanied by currency and credit strategies and focused on strengthening the entire productive chain. They are defined as an expression of developmentalism because they anticipate or neutralize structural constraints on production, thus reaffirming the role of rational development orientation.

The other angle of recent policies points, however, to the strategic role of popular consumption and income in the economic and social development process. The development path through mass consumption, direct cash transfer (such as Bolsa Familia), popular credit policies and social economy are important characteristics of a concept of economy stimulated by the "demand side" by the domestic market thesis and by innovation through the multiplication of popular entrepreneurship. Associated with the distribution of strategic resources of empowerment and generation of capabilities, it becomes distributive and inclusive in more ways than one. The direct cash transfer policy impacts on the change in local and regional economic dynamics - see the case of the Northeast (Araújo, 2006; 2007), on the gender issue and on the inclusion of the segments most affected by exclusion in the universe of a cash economy that produces rational calculation. ${ }^{7}$ Policies of indirect cash transfer via services and assets such as the "Light for All" and "My House My Life" programs, multiplication of rural settlements, among other foci, promote the inclusion of these actors in the ownership of larger shares of well-being and quality of life, but also increase awareness about the political Subject (holder and claimer of rights).

In terms of strategic redistribution of social power (empowerment, as proposed by Amartya Sen), we have the current policies of democratization of access to higher education provided by the policies to increase the number of places in public institutions (ReUni and network of higher technical institutions), funding of tuition for low income students in the private system (ProUni), and proposals for new selection/admission mechanisms (ENEM, SISU and Special School Places). Education can produce a long-term and far-reaching change, as it generates social mobility, political and symbolic inclusion, transformation of the cognitive areas of knowledge, and cultural expression. 
All together, direct and indirect cash transfer policies have a multiple role: economic - as they warm up the market, serving as a means of dynamism and incentive to industrial production, trade, services (mass consumption is to a large extent connected to the domestic market model of the old developmentalism); and political - since by including as consumer or owner, the logic of this inclusion, initially economic, is based on the principle of rights and citizenship as part of the social contract that enables demanding the promotion of well-being as one of the duties of the State.

Education expansion policies, Affirmative Actions and recognition of the principle of representation and organization of social differences express a second face of this inclusive role: to symbolically empower, instrumentally train and institutionally channel the flow of demands from different actors, allowing a change in the political power structure and its forms of implementation.

In the understanding of the political and economic arrangements of the new developmentalism, it is important to reconsider the importance of the social inequality issue (enhanced in analyzes of recent decades) and the weight of democratic engineering. Against the backdrop of the democratic and inclusive reengineering of the 1988 Constitution, the massification of the Brazilian electoral college and the coalition change of the groups in power, inclusion is a term (if not a currency) of extreme value and power ${ }^{8}$ in the construction of social commitments.

If the new developmentalism retains elements of the original model of the old developmentalism, such as the notion of integrated system and the leading role of the State in solving structural barriers for which the free action of individuals and the market are not strong enough to transform them, it has shifted, however, the focus of its purpose: the current deficiencies are of social nature, daughters of inequality and poverty.

I highlight here, to conclude this article, two innovations in the design and tools of new developmentalism. The first is characterized by a more specific and less direct economic intervention, with a lower level of nationalization, with the predominance of regulatory policies and less direct intervention. A second aspect is explained by the decrease in the State' autonomy, which submits to the control of society at two levels: social management and control (deliberative participation, accountability, managerial administration) and purpose of its action (via inclusion and distribution). The sum of these two institutional factors pose as central the notion of responsiveness and efficacy, while enhancing the corrective role of state action and establishing strict mechanisms of control over this action (legal, political- institutional or through elections). Although in a more flexible and specific manner, the Brazilian government in this period delivered a package of changes and policies that resume the objective of the old developmentalism, but not its modus operandi. The focus on economic logic is maintained, but demands related to the topic of distribution are defined as essential and submitted to various forms of social control. Public policies have 
changed paths, redefining priorities and instruments so as to enable the legitimate assumption of a new social pact in progress, but clear in terms of a process and not necessarily in a project.

\section{Notes}

1 Simonsen $(1940$, p.14 $)$, i.e.: the idea that the central obstacle to national development was productive failure, an argument that remained valid until the late 1970s (cf. Simonsen, 1931, 1934, 1944).

2 The coeval work of Celso Furtado $(1962,1964,1995)$ is a good expression of the tensions and configuration of that moment.

3 See taxonomy produced by Ricardo Bielschowsky (1988).

4 Interestingly, this statement was made in the 1930s, again by Simonsen, and reused by Delfim Neto during the military government - i.e., at the beginning and end of the old developmentalism cycle.

5 One of the few intellectuals to disagree with this proposition in the period was Furtado, by placing income distribution at the core of the dynamic for overcoming underdevelopment and defining development as a holistic project of cultural and institutional modernization with social equity (Furtado, 1967 and 1962 1964).

6 See designation given by List (1986).

7 See in this regard the excellent analysis by Alessandro Pinzani and Walquiria Leão Rego in Vozes do Bolsa familia: dinheiro, autonomia e cidadania (in press).

8 About the electoral political reach, see excellent analysis by André Singer (2009).

\section{References}

ALBUQUERQUE, R. C. O desenvolvimento social do Brasil. Rio de Janeiro: José Olympio, 2011.

AGARWALA, A. N.; SINGH, S. P. (Coord.) A economia do subdesenvolvimento. Rio de Janeiro: Forense, 1969.

ARAÚJO, T. B. Desenvolvimento regional: a descentralização valorizaria a diversidade. In: FLEURY, S. (Org.) Democracia, descentralização e desenvolvimento - Brasil \& Espanba. Rio de Janeiro: Editora FGV, 2006. p.373-96.

. Brasil: desafios de uma política nacional de desenvolvimento regional. In: DINIZ,

C. C. (Org.) Politicas de desenvolvimento regional. Brasília: UnB, 2007. p.221-36.

BIELSCHOWSKY, R. Pensamento econômico brasileiro. Rio de Janeiro: IPEA; INPES, 1988.

BIELSCHOWSKY, R.; MUSSI, C. Politicas para a retomada do crescimento-reflexões de economistas brasileiros. Brasília: IPEA; ECLAC, 2002.

BRANDÃO, G. M. Linbagens do pensamento politico brasileiro. São Paulo: Hucitec, 2007.

BRESSER-PEREIRA, L. C. Construindo o Estado republicano - democracia e reforma da gestão pública. Rio de Janeiro: FGV, 2009. 
Os três ciclos da sociedade e do Estado. Discussion paper 308. São Paulo: FGV-EESP, abril 2012.

CARDOSO, F. H.; FALETTO, E. Dependência e desenvolvimento na América Latina. México: Siglo XXI, 1969.

CEPÊDA, V. A. Contexto política e crítica à democracia liberal: a proposta de representação classista na Constituinte de 1934. In: MOTA, C. G.; SALINAS, N. (Org.) Os juristas na formação do Estado-Nação brasileiro: de 1930 aos dias atuais. São Paulo: Saraiva; FGV, 2010. p.195-222.

FURTADO, C. Desenvolvimento e subdesenvolvimento. Rio de Janeiro: Fundo de Cultura, 1961 .

. A pré-revolução brasileira. Rio de Janeiro: Fundo de Cultura, 1962.

. Dialética do desenvolvimento. Rio de Janeiro: Fundo de Cultura, 1964.

- Teoria e politica do desenvolvimento econômico. São Paulo: Cia. Editora Nacional, 1967.

Formação econômica do Brasil. 23.ed. São Paulo: Cia. Editora Nacional, 1995. LEWIS, W. A. A teoria do desenvolvimento econômico. Rio de Janeiro: Zahar, 1960.

LIST, G. F. Sistema nacional de economia politica. São Paulo: Nova Cultural, 1986. MANOILESCU, M. Teoria do protecionismo e da permuta internacional. São Paulo: Escolas Profissionais do Lyceu Coração de Jesus, 1931.

NURKSE, R. Problemas de formação de capital em paises subdesenvolvidos. Rio de Janeiro: Civilização Brasileira, 1957.

O’DONNEL, G. Análise do autoritarismo burocrático. Rio de Janeiro: Paz e Terra, 1990.

POCHMANN, M. Desenvolvimento e perspectivas novas para o Brasil. São Paulo: Cortez, 2010.

ROSTOW, W. W. Etapas do desenvolvimento econômico. Rio de Janeiro: Zahar, 1964. SACHS, W. Dicionário do desenvolvimento. Rio de Janeiro: Vozes, 2000.

SALLUM JUNIOR, B. Metamorfoses do Estado brasileiro no século XX. Revista Brasileira de Ciências Sociais, São Paulo, ANPOCS, v.18, n.52, p.35-54, June 2003.

SEN, A. Desenvolvimento como liberdade. São Paulo: Cia. das Letras, 2000.

SICSÚ, J.; CASTELAR, A. (Org.) Sociedade e economia: estratégias de crescimento e desenvolvimento. Brasília: IPEA, 2009.

SICSÚ, J. et al. (Org.) Novo-desenvolvimentismo: um projeto nacional de crescimento com equidade social. Barueri: Manole; Rio de Janeiro: Fundação Konrad Adenauer, 2005.

SIMONSEN, R. As finanças e a indústria. São Paulo: São Paulo Editora, 1931.

. Ordem econômica, padrão de vida e algumas realidades brasileiras. São Paulo: São Paulo Editora, 1934.

Niveis de vida e a economia nacional. São Paulo: s. n., 1940.

Planificação da economia brasileira - parecer apresentado ao CNPIC. São Paulo:

FIESP, 1944. 
SINGER, A. Raízes sociais e ideológicas do Lulismo. Revista Novos Estudos CEBRAP, São Paulo, v.85, p.83-102, 2009.

STIGLITZ, J. E. A globalização e seus malefícios. São Paulo: Futura, 2002. VIANNA, O. O idealismo da Constituição. Rio de Janeiro: Terra do Sol, 1927.

ABSTRACT - This paper analyzes the process of Brazilian developmentalism between the classical phase of the 1950s to the current perspective of new developmentalism, emphasizing the role and function played by the theme of democracy and distributive inclusion in every arrangement. In the first section, it is analyzed the semantic constellation involving the terms progress and development, seeking to separate them from the process / project called developmentalism. In the second section, it is discussed the phases and the central features of old and new Brazilian developmentalism and the prospect of their subdivision into three historical waves, separated by the political democratic aspect and by the theme of redistribution. Finally it presents some considerations about new developmentalism in its democratic-inclusive arrangement.

KEYWORDS: Democracy, Equity, Social justice, New developmentalism. 
Vera Alves Cepêda has a Master's Degree and a PhD in Political Science (USP). She is a professor in the Graduate Program in Political Science (PPGPol-UFSCar) and at the Department of Social Sciences-UFSCar.

@-veracepeda@ufscar.br / cepeda_vera@yahoo.com.br

Received on 18 May 2012 and accepted on 8 June 2012. 